\title{
ИССЛЕДОВАНИЯ МЕХАНИЗМОВ ДЕЙСТВИЯ ПОЛОЖИТЕЛЬНЫХ И ОТРИЦАТЕЛЬНЫХ МОДУЛЯТОРОВ ИОНОТРОПНЫХ ГЛУТАМАТНЫХ РЕЦЕПТОРОВ
}

\author{
В.А. Палюлинн, ${ }^{1,2}$ М.И. Лавров ${ }^{1,2}$, Е.В. Радченко,2, А.С. Тараканова', \\ Е.А. Голубева', Д.С. Карлов', Е.Б. Аверина, ${ }^{1,2}$, К.Н. Седенкова ${ }^{1,2}$, \\ Д.А. Василенко', А.А. Назарова', Н.С. Темнякова', П.Н. Веремеева', \\ Т.В. Вьюнова ${ }^{3}$, В.Л. Замойский ${ }^{2}$, В.В. Григорьев ${ }^{1,2}$ \\ ${ }^{1}$ Химический факультет МГУ имени М.В.Ломоносова, 119991, Россия, г. Москва. \\ ${ }^{2}$ Институт физиологически активных веществ РАН, 142432, Россия, г. Черноголовка. \\ ${ }^{3}$ Институт молекулярной генетики РАН, 123182, Россия, г. Москва
}

DOI: 10.19163/MedChemRussia2021-2021-165

E-mail:vap@qsar.chem.msu.ru

В последние годы большое внимание уделяется созданию новых нейропротекторных препаратов, основной мишенью которых служит глутаматергическая система - главная возбуждающая медиаторная система мозга млекопитающих. АМРА-рецепторы, один из подтипов глутаматных рецепторов, участвуют во многих нейрофизиологических процессах, задействованных в системе передачи быстрого синаптического возбуждения, формировании памяти и др. Основой терапевтического потенциала аллостерических модуляторов АМРА-рецепторов служит их способность значительно увеличивать синаптическую пластичность и экспрессию нейротрофических факторов, что является основным механизмом регенерации нервной ткани.

В докладе обсуждаются результаты применения системы молекулярного функционального скрининга аллостерических модуляторов ионотропных глутаматных рецепторов с использованием как вычислительных подходов (включая длительное моделирование молекулярной динамики), так и ряда экспериментальных методов (электрофизиологические исследования методом patch clamp, анализ радиолигандного связывания с рецепторами, поведенческие тесты in vivo и др.). Показано, что соединения на основе двух скаффолдов - производные 3,7-диазабицикло[3.3.1]нонана и 1,11-диметил3,6,9-триазатрицикло[7.3.1.1]тетрадекан-4,8,12-триона, хорошо связывающиеся с модуляторными сайтами АМРА-рецептора и вызывающие при этом положительный или отрицательный эффект, могут иметь и другие биомишени. Благодаря эффекту синергии такие соединения могут быть использованы для создания качественно новых лекарственгных препаратов для лечения нейродегенеративных расстройств различного генеза.

Работа выполнена при поддержке Российского научного фонда

(грант № 17-15-01455).

$$
-165-
$$

